\title{
Biological decolorization of xanthene dyes by anaerobic granular biomass
}

\author{
Laura Carmen Apostol • Luciana Pereira • \\ Raquel Pereira • Maria Gavrilescu • \\ Maria Madalena Alves
}

Received: 23 August 2011/ Accepted: 8 March 2012/Published online: 22 March 2012

(C) Springer Science+Business Media B.V. 2012

\begin{abstract}
Biodegradation of a xanthene dyes was investigated for the first time using anaerobic granular sludge. On a first screening, biomass was able to decolorize, at different extents, six azo dye solutions: acid orange 7 , direct black 19 , direct blue 71 , mordant yellow 10, reactive red 2 and reactive red 120 and two xanthene dyes-Erythrosine B and Eosin Y. Biomass concentration, type of electron donor, induction of biomass with dye and mediation with activated carbon (AC) were variables studied for Erythrosine B (Ery) as model dye. Maximum color removal efficiency was achieved with $4.71 \mathrm{~g} \mathrm{VSS} \mathrm{L}^{-1}$, while the process rates were independent of the biomass concentration above $1.89 \mathrm{~g} \mathrm{VSS} \mathrm{L}^{-1}$. No considerable effects were observed when different substrates were used as electron donors (VFA, glucose or lactose). Addition of Ery in the incubation period of biomass led to a fivefold increase of the decolorization rate. The rate of Ery decolorization almost duplicated in the presence of commercial $\mathrm{AC}\left(0.1 \mathrm{~g} \mathrm{~L}^{-1} \mathrm{AC}_{0}\right)$. Using different
\end{abstract}

L. C. Apostol · M. Gavrilescu ( $\square)$

Department of Environmental Engineering and

Management, Faculty of Chemical Engineering and Environmental Protection, "Gheorghe Asachi"

Technical University of Iasi, 73 Prof.dr.docent Dimitrie

Mangeron Street, 700050 Iasi, Romania

e-mail: mgav@tuiasi.ro;mgav_ro@yahoo.com

L. Pereira $\cdot$ R. Pereira · M. M. Alves

IBB-Instituto Biotecnologia e Bioengenharia,

Centro Engenharia Biológica, Universidad do Minho,

Campus de Gualtar, 4710-057 Braga, Portugal modified $\mathrm{AC}$ samples (from the treatment of $\mathrm{AC}_{0}$ ), a threefold higher rate was obtained with the most basic one, $\mathrm{AC}_{\mathrm{H}_{2}}$, as compared with non-mediated reaction. Higher rates were obtained at $\mathrm{pH}$ 6.0. Chemical reduction using $\mathrm{Na}_{2} \mathrm{~S}$ confirmed the recalcitrant nature of this dye. The results attest that decolorization of Ery is essentially due to enzymatic and adsorption phenomena.

Keywords Anaerobic process - Biological decolorization $\cdot$ Eosin $\cdot$ Erythrosine $\cdot$ Xanthene dyes
Abbreviations
AC Activated carbon
$\mathrm{AC}_{0} \quad$ NoritROX0.8 activated carbon
$\mathrm{AC}_{\mathrm{O}_{2}} \quad$ Surface modified activated carbon, prepared by chemical oxidation $\mathrm{O}_{2}$ and thermal treatments under $\mathrm{H}_{2}\left(\mathrm{AC}_{\mathrm{H}_{2}}\right)$ or $\mathrm{N}_{2}$ $\left(\mathrm{AC}_{\mathrm{N}_{2}}\right)$ flow
$\mathrm{AC}_{\mathrm{HNO}_{3}}$ Surface modified activated carbon, prepared by chemical oxidation with $\mathrm{HNO}_{3}$ $\left(\mathrm{AC}_{\mathrm{HNO}_{3}}\right)$
$\mathrm{AC}_{\mathrm{H}_{2}} \quad$ Activated carbon treatments under $\mathrm{H}_{2}$ $\left(\mathrm{AC}_{\mathrm{H}_{2}}\right)$ or $\mathrm{N}_{2}\left(\mathrm{AC}_{\mathrm{N}_{2}}\right)$ flow
$\mathrm{AC}_{\mathrm{N}_{2}} \quad$ Activated carbon treatments under $\mathrm{N}_{2}$ $\left(\mathrm{AC}_{\mathrm{N}_{2}}\right.$ flow
COD Chemical oxygen demand $\left(\mathrm{mg} \mathrm{O}_{2} \mathrm{~L}^{-1}\right)$
C.I. Colour index
DAD Diode array detector
Ery Erythrosine B
Eos Y Eosin Y 
VSS Volatile suspended solids

AO7 Acid orange 7

DB19 Direct black 19

DB71 Direct blue 71

MY10 Mordant yellow 10

RR2 Reactive red 2

RR120 Reactive red 120

\section{Introduction}

A variety of synthetic dye stuffs are released by industry during manufacturing processes. Their presence in the environment is of greater concern, since they may generate serious public health and environmental problems. Some of these compounds have mutagenic or carcinogenic activity (Caliman and Gavrilescu 2009; Gavrilescu 2009). Several techniques (chemical, physical, and biological) may be applied for the decolorization of wastewater containing dyes, but each method has technical and economic limitations (Apostol and Gavrilescu 2009; Cailean et al. 2009; Caliman and Gavrilescu 2009; Momenzadeh et al. 2011; SenthilKumar et al. 2010).

Biological treatment methods may be preferred for decolorization as environmentally friendly and relatively inexpensive ones (Costa et al., 2009; Van der Zee and Villaverde, 2005; Gavrilescu and Chisti, 2005). Anaerobic treatment generally gives good color removal efficiencies in opposition with aerobic conditions where low color removal efficiencies are achieved, because oxygen is a more efficient electron acceptor, therefore having more preference for electrons than azo dyes (Dos Santos et al. 2004). Treatment systems composed of mixed microbial populations achieve a higher degree of biodegradation and mineralization due to the synergistic metabolic activities of the microbial community and have considerable advantages over the use of pure cultures (Saratale et al. 2011; Venkata Mohan et al. 2011). In a microbial consortium, the individual strains may attack the dye molecule at different positions or utilize metabolites produced by the co-existing strains for further decomposition (Saratale et al. 2011). Most of the research focuses on the anaerobic decolorization of the most representative class of dyes, azo compounds (Firmino et al. 2010; Saratale et al. 2011).
Xanthene represent a distinct class of dyes that are use in food, cosmetics, paper, and ink, due to superior dyeing and coloring properties, but have poor biodegradability and some of them are toxic (Itoh and Yatome 2004). Only six reports on enzymatic oxidation of xanthene dyes are available (Itoh and Yatome 2004; Jesus et al. 2010) and any about enzymatic reduction.

The aim of this study was to test and investigate the effect of non-acclimated anaerobic granular sludge on a xanthene dye, Erythrosine B (Ery B), under batch anaerobic conditions; this being a first report on the decolorization of xanthene dyes containing solutions by a mixed anaerobic culture.

The results in batch and in continuous assays, can give different conclusions, especially in the case of biological degradation with mixed cultures. However, as a starting approach for this type of studies, batch assays are useful and indicative of expected kinetics. From the indication of the batch assays we anticipate a difficult anaerobic biodegradability of this dye, even in continuous assays. Different approaches, combining oxidative and biological processes or redox mediators among others, are being tested.

A first screen of dye biodegradation by the biomass was done for six model azo dyes-acid orange 7 , direct black 19, direct blue 71, mordant yellow 10 , reactive red 2 and reactive red 120 and two xanthene dyes-Ery B and Eosin. Ery B was selected for further studies on the biological degradation of xanthene dyes. The effect of various parameters on the Ery biodegradation was then, for the first time, studied: (i) biomass concentration; (ii) electron donor (VFA, glucose, and lactose); (iii) biomass induction with dye; (iv) pH; and (v) dye concentration. The transfer of reducing equivalents from a primary electron donor (co-substrate) to a terminal electron acceptor (azo dye) generally acts as the process rate limiting step in anaerobic azo dye reduction (Van der Zee et al. 2003) and activated carbon, as an insoluble catalyst, has been shown as a good alternative to the soluble ones, with the advantage of being recovered and reused with facility. For the first time, the effect of a redox mediator on xanthene dyes biodegradation was assessed by adding a commercial $\left(\mathrm{AC}_{0}\right)$ and surface modified activated carbon samples, prepared by chemical oxidation with $\mathrm{HNO}_{3}\left(\mathrm{AC}_{\mathrm{HNO}_{3}}\right)$ and $\mathrm{O}_{2}$ $\left(\mathrm{AC}_{\mathrm{O}_{2}}\right)$ and thermal treatments under $\mathrm{H}_{2}\left(\mathrm{AC}_{\mathrm{H}_{2}}\right)$ or $\mathrm{N}_{2}$ $\left(\mathrm{AC}_{\mathrm{N}_{2}}\right)$ flow (Pereira et al., 2010). Besides in a 
biological system, Ery reduction was assessed with different concentrations of a known chemical reducing agent, $\mathrm{Na}_{2} \mathrm{~S}$ (Cervantes et al. 2007; Pereira et al. 2010; Van der Zee et al. 2001). Work in order to obtain the biodegradation products is ongoing and we aim to provide the information in near future publications.

\section{Experimental}

\section{Chemicals}

The xanthene dyes used were the Erythrosine B (Ery B, C.I. 45430, dye content $95 \%$ ) and Eosin Y (Eos Y,
C.I. 45380, dye content $85 \%$ ). The azo dyes acid orange 7 (AO7, C.I. 15510, dye content $85 \%$ ), direct black 19 (DB19, C.I. 35255, dye content $50 \%$ ), direct blue 71 (DB71, C.I. 34140, dye content $50 \%$ ), mordant yellow 10 (MY10, C.I. 14010, dye content $85 \%$ ); reactive red 2 (RR2, dye content $40 \%$ ) and reactive red 120 (RR120, dye content $50 \%$ ), were selected as azo dye model compounds. All the dyes were purchased from Sigma-Aldrich and used without additional purification. The chemical structures of the dyes are illustrated in Fig. 1. Stock solutions of $14 \mathrm{mM}$ were prepared in deionized water.

NoritROX0.8 commercial activated carbon type (pellets of $0.8 \mathrm{~mm}$ diameter and $5 \mathrm{~mm}$ length) was<smiles></smiles>

Erythrosine B (ERY)<smiles>O=S(=O)(O)c1ccc(N=Nc2c(O)ccc3ccccc23)cc1</smiles>

Acid Orange 7 (AO7)

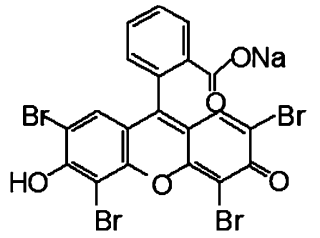

Eosine $Y(E O S)$<smiles>O=C(O)c1cc(N=Nc2ccc(S(=O)(=O)O[Na])cc2)ccc1O</smiles>

Mordant Yellow 10 (MY10)

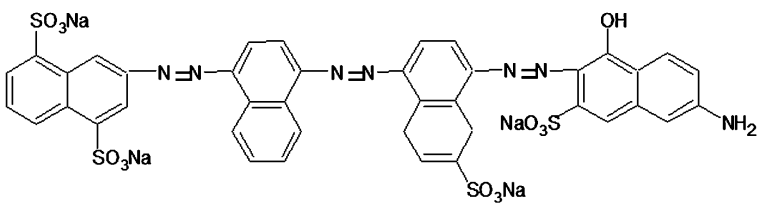

Direct Blue 71 (DB71)

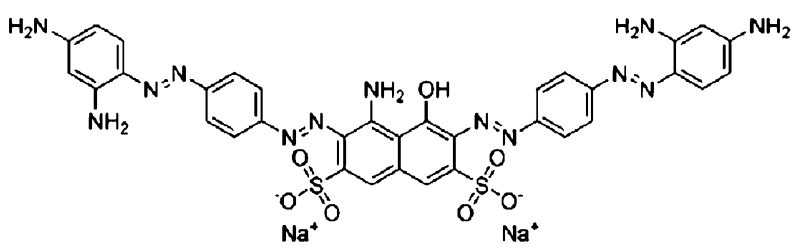

Direct Black 19 (DB19)

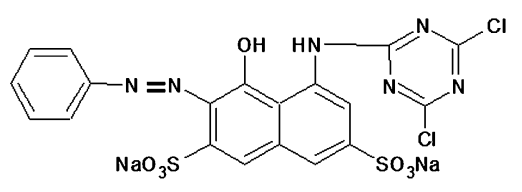

Reactive Red 2 (RR2)

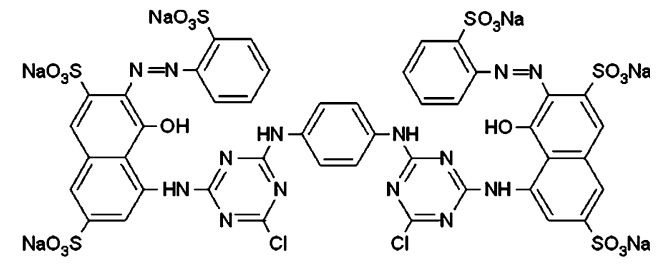

Reactive Red 120 (RR120)

Fig. 1 Molecular structure of the azo and xanthene dyes 
used, as supplied by Norit (the registered mark of Noric Americas Inc.), as a starting material (sample $\mathrm{AC}_{0}$ ). $\mathrm{AC}$ samples with different chemical composition on the surface, maintaining the original textural properties as much as possible, were prepared by chemical oxidation $\left(\mathrm{AC}_{\mathrm{HNO}_{3}}\right.$ and $\left.\mathrm{AC}_{\mathrm{O}_{2}}\right)$ or thermal treatment $\left(\mathrm{AC}_{\mathrm{N}_{2}}\right.$ and $\mathrm{AC}_{\mathrm{H}_{2}}$ ) and characterized in Engineering Faculty of Porto University as described by Pereira et al. (2010).

The substrates, macronutrients and sodium sulphide $\left(\mathrm{Na}_{2} \mathrm{~S}\right)$ were all from Sigma or Fluka, at the highest analytic grade purity commercially available.

Granular anaerobic biomass

Non-acclimated anaerobic granular sludge was collected from wastewater treatment plant of "Central de Cervejas", Vialonga, Portugal. The volatile suspended solids content of the biomass was determined as $0.0943 \mathrm{~g} \mathrm{VSS} \mathrm{g}^{-1}$.

Dye degradation by anaerobic granular biomass

Eight model dyes were screened for biodegradation using an anaerobic granular biomass: three azo (AO7, MY10 and RR2), a disazo (RR120), a trisazo (DB71), a poliazo (DB19) and two xanthene dyes (Ery and Eos). Batch assays were conducted in $120 \mathrm{~mL}$ serum bottles with butyl rubber stopper, containing the biomass, 0.94 g VSS L ${ }^{-1}$, the substrate and macronutrients in a total volume of $50 \mathrm{~mL}$ of medium, that was buffered at a $\mathrm{pH}$ of $7 \pm 0.2$ with $\mathrm{NaHCO}_{3}\left(2.5 \mathrm{~g} \mathrm{~L}^{-1}\right)$. The headspace of the serum bottles was flushed with the $\mathrm{N}_{2}: \mathrm{CO}_{2}(80 / 20$ $\mathrm{v} / \mathrm{v}$ ) and pre-incubation of the sludge was done overnight at $37{ }^{\circ} \mathrm{C}$, in a rotary shaker at $120 \mathrm{rpm}$. As macronutrients, $2.8 \mathrm{~g} \mathrm{~L}^{-1} \mathrm{NH}_{4} \mathrm{Cl}, 2.5 \mathrm{~g} \mathrm{~L}^{-1} \mathrm{KH}_{2} \mathrm{PO}_{4}$, $1 \mathrm{~g} \mathrm{~L}^{-1} \mathrm{MgSO}_{4} \cdot 7 \mathrm{H}_{2} \mathrm{O}$ and $0.06 \mathrm{~g} \mathrm{~L}^{-1} \mathrm{CaCl}_{2}$ were added. Volatile fatty acids (VFAs: acetic, propionic, and butyric acid, 1:10:10) were supplemented as electron source for the reduction $\left(2 \mathrm{~g} \mathrm{COD} \mathrm{L}^{-1}\right)$. After the preincubation period, the dye was added with a syringe from the stock solution to a final concentration of $0.3 \mathrm{mM}$. The serum bottles were further incubated at $37^{\circ} \mathrm{C}$ in a rotary shaker at $120 \mathrm{rpm}$, for 1 day. All the experiments were prepared in triplicate.

\section{Biological Ery B degradation}

For the anaerobic biological dye degradation, batch assays were performed in the same conditions as described before. Various parameters that could affect the reaction were evaluated: biomass concentration $\left(0.94,1.89,3.77\right.$, and $\left.4.71 \mathrm{~g} \mathrm{VSS} \mathrm{L}^{-1}\right)$; dye concentration (0.1-0.6 mM); substrate (VFAs, glucose, lactose, $2 \mathrm{~g} \mathrm{COD} \mathrm{L}^{-1}$ ) and biomass induction with dye ( $0.03 \mathrm{mM}: 10 \%$ of the use in decolourisation assay). The effect of activated carbon (AC) as redox mediator was also studied by incubation with $0.1 \mathrm{~g} \mathrm{~L}^{-1}$ and $0.5 \mathrm{~g} \mathrm{~L}^{-1}$ of commercial and surface modified AC. In these assays, the amount of biomass used was 0.94 or $3.77 \mathrm{~g} \mathrm{VSS} \mathrm{L}^{-1}$. In order to evaluate the dye adsorption on AC, assays in the same conditions but without biomass were conducted in parallel. Isotherms of adsorption on AC were also determined according to Potgieter (1991), with $\mathrm{AC}_{0}$ concentrations between 0.1 and $0.5 \mathrm{~g} \mathrm{~L}^{-1}$ and dye concentration of $0.3 \mathrm{mM}$. Batch experiments using $0.3 \mathrm{mM}$ of Ery in the presence or absence of $0.1 \mathrm{~g} \mathrm{~L}^{-1}$ of $\mathrm{AC}_{0}$, in the same conditions but at $\mathrm{pH} 6$, were also run with the aim of evaluating how the $\mathrm{pH}$ decrease to six could affect the reactions.

\section{Adsorption of Ery B on biomass}

With the purpose of estimating the dye adsorption on biomass, batch assays were performed in the same conditions as described previously, using $0.3 \mathrm{mM}$ of Ery B, with inactive (autoclaved at $120{ }^{\circ} \mathrm{C}$, for $1 \mathrm{~h}$ ) or inhibited biomass ( $3.77 \mathrm{~g} \mathrm{VSS} \mathrm{L}^{-1}$ ). Inhibition was done by immersing the biomass (previous washed with PBS - phosphate buffered saline) in $2.5 \%(\mathrm{v} / \mathrm{v})$ of a glutaraldehyde solution and $37 \%$ of formaldehyde. These two aldehyde fixatives are frequently used in light and electron microscopy (Artvinli 1975).

Fixation stabilizes and cross-links organic molecules within the cellular material, thus preserving the morphology and making the cells more resistant to subsequent treatments.

Glutaraldehyde significantly changes the physical, chemical, and biological characteristics of proteins, although its penetration is slow and heterogeneous.

It decreases the affinity of cell wall proteins for acid dyes, probably as a result of the rapid blocking of amino groups of the proteins. This effect may also occur with tissue proteins. Contrary, formaldehyde penetrates the tissues homogeneously, rapidly terminates the catabolic reactions, and only slightly denatures the proteins (Artvinli 1975). Thus, glutaraldehyde-formaldehyde 
solution can be suitable for tissue preparative techniques when the fixation time is reduced.

VFAs were used as substrate. Biological solutions decolorization with active biomass (3.77 $\mathrm{g} \mathrm{VSS} \mathrm{L}^{-1}$ ) but without nutrients and carbon source was also assayed.

\section{Chemical Ery B reductions}

Batch assay were performed for chemical reduction of Ery using $\mathrm{Na}_{2} \mathrm{~S}$. The effect of $\mathrm{pH}$ was evaluated in the range of 4-10. Batch assays were performed in $120 \mathrm{~mL}$ serum bottles closed with butyl rubber stopper, containing $50 \mathrm{~mL}$ of $100 \mathrm{mM}$ Britton Robinson (BR) buffer (100 mM phosphoric acid, $100 \mathrm{mM}$ boric acid and $100 \mathrm{mM}$ acetic acid titrated to the desired $\mathrm{pH}$ with $0.5 \mathrm{M} \mathrm{NaOH})$. The bottles were flushed with the $\mathrm{N}_{2}: \mathrm{CO}_{2}(80 / 20 \mathrm{v} / \mathrm{v})$ and a volume to give the $\mathrm{Na}_{2} \mathrm{~S}$ desired concentration (in the range 1$6 \mathrm{mM}$ ) was added with a syringe. The bottles were pre-incubated overnight at $37{ }^{\circ} \mathrm{C}$, in a rotary shaker at $120 \mathrm{rpm}$. After the pre-incubation period, $0.3 \mathrm{mM}$ of dye was added with a syringe from the stock solution. The serum bottles were further incubated at $37{ }^{\circ} \mathrm{C}$ in a rotary shaker at $120 \mathrm{rpm}$. The process reaction was monitored visually. In order to study the effect of sodium sulphide concentration, an assay with higher amount, $100 \mathrm{mM}$, was also conducted, at $\mathrm{pH} 7$, and the reaction was monitored spectrophotometricaly.

\section{Analytical techniques}

Color decrease was monitored spectrophotometricaly in a 96-well plate reader (ELISA BIO-TEK, Izasa). At select intervals, samples were withdrawn $(300 \mu \mathrm{L})$, centrifuged at $5000 \mathrm{rpm}$ for $10 \mathrm{~min}$ to remove the biomass and/or AC and diluted, with the same buffer as of the reaction, to obtain less than one absorbance unit (AU), due to the high absorbance of the dye, even at low concentrations. The visible spectra (300-900 nm) were recorded and dye concentration calculated at $\lambda_{\text {max }}$. Molar extinction coefficients were determined for each dye at $\lambda_{\text {max }}: \varepsilon_{524 \mathrm{~nm}}=67,282 \mathrm{M}^{-1} \mathrm{~cm}^{-1}$ for Ery; $\varepsilon_{510 \mathrm{~nm}}=60,826 \mathrm{M}^{-1} \mathrm{~cm}^{-1}$ for Eos; $\varepsilon_{480 \mathrm{~nm}}=$ $9,600 \mathrm{M}^{-1} \mathrm{~cm}^{-1}$ for AO7; $\varepsilon_{540 \mathrm{~nm}}=28,637 \mathrm{M}^{-1}$ $\mathrm{cm}^{-1}$ for RR2; $\varepsilon_{350 \mathrm{~nm}}=15,519 \mathrm{M}^{-1} \mathrm{~cm}^{-1}$ for MY10; $\varepsilon_{590 \mathrm{~nm}}=76,716 \mathrm{M}^{-1} \mathrm{~cm}^{-1}$ for DB71; $\varepsilon_{660 \mathrm{~nm}}=$ $12,813 \mathrm{M}^{-1} \mathrm{~cm}^{-1}$ for DB19 and $\varepsilon_{510 \mathrm{~nm}}=4,934 \mathrm{M}^{-1}$ $\mathrm{cm}^{-1}$ for RR120. All the experiments were prepared in triplicate.

Color removal (R) was calculated according to Eq. 1:

$R(\%)=\frac{A_{0}-A_{t}}{A_{0}} \times 100$

where $A_{0}$, is the absorbance for $\lambda_{\max }$ at the beginning of incubation and $A_{t}$, the absorbance at $\lambda_{\max }$ at a selected time $(\mathrm{t})$.

First-order reduction rate constants were calculated in OriginPro 6.1 software, applying the equation $\mathrm{C}_{\mathrm{t}}=\mathrm{C}_{\mathrm{o}}+\mathrm{C}_{\mathrm{i}} \mathrm{e}^{-\mathrm{kt}}$, where $\mathrm{C}_{\mathrm{t}}$ is the concentration at time $t ; C_{o}$, the offset; $C_{i}$, the concentration at time initial time; $\mathrm{k}$, the first-order rate constant $\left(\mathrm{h}^{-1}\right)$ and $\mathrm{t}$ is the accumulated time of the experiment.

HPLC analyses were performed in a HPLC (JASCO AS-2057 Plus) equipped with a DAD (Diode Array Detector) detector. A C18 reverse phase Nucleodur MNC18 $(250 \times 4.0 \mathrm{~mm}, 5 \mu \mathrm{M}$ particle size and pore of $100 \AA$ from Machenerey-Nagel, Switzerland) column was used. The following solvent systems were used as mobile phase: solvent A (ACN) and solvent B (Sodium acetate buffer, $\mathrm{pH}$ 5.3). Compounds were eluted at a flow rate of $0.7 \mathrm{~mL} \mathrm{~min}^{-1}$ and at room temperature, with a linear gradient of mobile phase from 10 to $100 \%$ of solvent A, over $15 \mathrm{~min}$, followed by isocratic condition with $100 \%$ of solvent A over 10 min. Compounds elution was monitored at $\lambda_{\max }$ of each dye and $230 \mathrm{~nm}$.

\section{Results and discussion}

Dye biodegradation

The studies regarding azo dye anaerobic reduction indicated that the process is a non-specific and presumably extracellular process, in which reducing equivalents from either biological or chemical source are transferred to the dye (van der Zee et al. 2000, 2003; Ong et al. 2005; Karatas et al. 2009). All azo dyes tested in our experiments were, at a different extent, reductively degraded by the granular biomass (Table 1).

Previous studies carried out by van der Zee et al. (2000, 2003) on azo dyes chemical decolorization using sulphide pointed out the presence of a lag phase: the reaction rates were initially slow, but accelerated 
Table 1 Screening for the biological decolorization of different dye solutions $(0.3 \mathrm{mM}$ of dye). Batch assays were conducted at $37{ }^{\circ} \mathrm{C}$ and $120 \mathrm{rpm}$ (The amount of anaerobic granular biomass was $0.94 \mathrm{~g} \mathrm{VSS} \mathrm{L}^{-1}$; as electron donor was used VFAs)

\begin{tabular}{lll}
\hline Dye & Class & Decolorization (\%) \\
\hline Acid orange 7 & Azo & $73 \pm 3$ \\
Direct black 19 & Azo & $26 \pm 6$ \\
Direct blue 71 & Azo & $69 \pm 2$ \\
Mordant yellow 10 & Azo & $87 \pm 1$ \\
Reactive red 2 & Azo & $55 \pm 1$ \\
Reactive red 120 & Azo & $87 \pm 4$ \\
Erythrosine B & Xanthene & $20 \pm 4$ \\
Eosin Y & Xanthene & $7 \pm 1$ \\
\hline
\end{tabular}

in time according to the extent to which the dye was reduced. Based on these observations, it was hypothesized that products of azo dye reduction may increase the rate of the reduction process, i.e., the reaction has an autocatalytic nature.

In our study, biodegradation of all dyes proceeded without lag periods and followed the first-order kinetics, since decolorization in anaerobic sludge environments is a combined process of biotic and abiotic reactions. Ong et al. (2005) shows that azo dyes can be reduced in a direct chemical reaction with bulk biogenic reducing agents, but they can also be reduced by biological reactions, either directly as an enzymatically catalyzed reaction or indirectly via reduced enzyme cofactors. The indirectly biological reduction (redox mediator catalyzed) of the dye, which acts as a redox mediator, may determine the increment of the biodegradation rate. A similar situation was discussed by van der Zee et al. (2003).

Better results were obtained for MY10 and RR120, $\sim 90 \%$. High degradation degrees were also obtained for $\mathrm{AO} 7$ and DB71, $70 \%$, and, at less extent, for RR2, $55 \%$. The poliazo DB19 was the azo dye degraded at lower extent, $26 \%$.

The xanthene dyes tested were more recalcitrant, with color decrease of merely $20 \%$ and $7 \%$, for Ery and Eos, respectively. Most of the decolorization studies using anaerobic sludge bacteria concentrate on azo dye containing solutions. Due to the lack of information available on xanthene dyes biodegradation, Ery B, though the low degradation obtained in the conditions tested, was chosen as a substrate for further studies. Only one work on Ery B biodegradation is available (Pereira et al. 2009). Jesus et al. (2010) results on dye removal by the fungus Neurospora crassa 74A suggested the possibility of biodegradation in proportion to the contact time between the dye and the fungal biomass. Itoh and Yatome (2004) have reported the aerobic biodegradation of six other xanthene dyes also by a white rot fungus, Coriolus versicolor, but as compared to our results with anaerobic bacterial biomass, where color removal occurred in few hours, their process took some days. Indeed, the decolorization of fluorescein, 4-aminofluorescein, and 5-aminofluorescein, all containing - $\mathrm{OH}$ groups, with growing cells was 79, 51, and $52 \%$ after 7 days and 85, 95, and $92 \%$ after 14 days incubation, respectively. With the other three xanthene dyes that they have tested, Rhodamine B, Rhodamine 123 hydrate, and Rhodamine $6 \mathrm{G}$, not containing $\mathrm{OH}$ groups, color removal was not observed. With cell free extracts of Coriolous versicolor only the first three dye solutions were decolorized as well. Oxidation of the dyes was attributed to the enzymatic action of a laccase. Enzymatic oxidation of Rhodamine B by a Trametis versicolor laccase was reported by Khammuang and Sarnthima (2009). Xanthene dyes oxidation by a horseradish peroxidase (HRP) was found to occur only in the presence of the natural compound indole-3-acetic acid (IAA) in $\mathrm{O}_{2}$-containing solutions (Krilov and Chebotareva 1993). More recently, Lan et al. (2006) have reported on the degradation of Rhodamine B with a lignin peroxidase coupled with glucose oxidase.

\section{Biological degradation of Ery B}

\section{Effect of biomass amount}

Degradation of Ery B was studied at different initial sludge concentrations. The UV-visible spectra with $1.89 \mathrm{~g} \mathrm{VSS} \mathrm{L}^{-1}$ of biomass show a decrease of the maximum band, corresponding to $46 \%$ of color removal. No new peaks corresponding to products formation were observed in the spectrum recorded after the treatment, $24 \mathrm{~h}$ (Fig. 2a). In the HPLC chromatogram, a decrease of the peak at the retention time $\left(R_{t}\right)$ of $10.1 \mathrm{~min}$, corresponding to Ery, was also obtained and $70 \%$ of decolorization calculated (the decolorization calculated value were not presented in Fig. 2a). Lower degrees of decolorization by spectrophotometry are expected since the color of substrate 

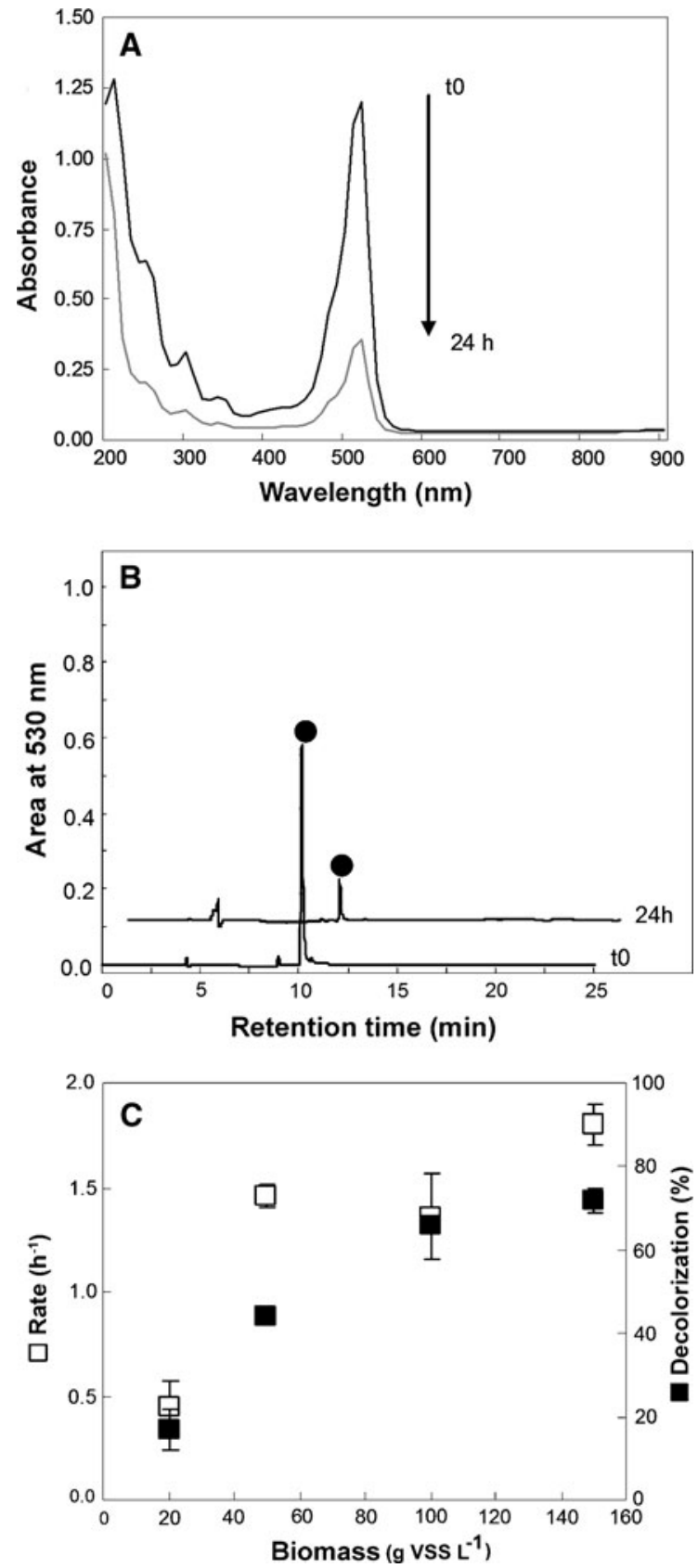

Fig. 2 UV-visible spectra of the of $0.3 \mathrm{mM}$ Erythrosine solution biological decolorization, with $1.89 \mathrm{~g} \mathrm{VSS} \mathrm{L}^{-1}$ of biomass (a); degree (filled square) and rates (open square) of Erythrosine B $(0.3 \mathrm{mM})$ solution biological decolorization at increasing biomass concentration (b) and at increasing dye concentrations (biomass concentration of $3.77 \mathrm{~g} \mathrm{VSS} \mathrm{L}^{-1}$ ) (c)

and products can contribute to the absorbance. On the other hand, by HPLC, the dye is chromatographically separated from products of the enzymatic reaction
(Pereira et al. 2009). The relationship between biomass amount, dye degradation rate and percentage is presented in Fig. 2b. As can be observed from Fig. 2c, color decrease displayed a saturation type of dependency with regard to sludge concentration, the removal percentage of dye increased with the increased of biomass amount and then leveled at $\sim 70 \%$ for higher than $3.77 \mathrm{~g} \mathrm{VSS} \mathrm{L}^{-1}$. The first order degradation rates have also increased with increase of the initial biomass concentration from $0.94 \mathrm{~g} \mathrm{VSS} \mathrm{L}^{-1}$ to $1.89 \mathrm{~g} \mathrm{VSS} \mathrm{L}^{-1}$, but for higher amounts it was maintained constant $\left(1.5 \mathrm{~h}^{-1}\right)$, even though the higher color removal degree with $3.77 \mathrm{~g}$ VSS L $^{-1}$ and $4.71 \mathrm{~g} \mathrm{VSS} \mathrm{L}^{-1}$ of biomass. Those results suggest the occurrence of two phenomena, dye enzymatic degradation, and adsorption. Indeed, after centrifugation, the granules were slightly colored. Several researchers have pointed out the capacity of various microbial biomasses (bacteria, yeasts, fungi, and algae) to absorb or accumulate dyes (Pearce et al. 2003; Crini 2006), which seems to take place essentially at the cell wall level. The main advantages of biosorption are its high selectivity and efficiency, good removal from large volumes and the potential cost effectiveness. Moreover, both living and dead biomasses can be used to remove hazardous organics. However, with living organisms higher decolorization of dyes aqueous solutions may be achieved due to the combination of both phenomena: adsorption and enzymatic degradation (Bakshi et al. 1999; Aretxaga et al. 2001). A saturation type curve of azo dye removal with increasing biomass concentration was also observed by Kalyuzhnyi et al. (2006). They have explained that, taking into account a regenerating function of sludge for reducing agents participating in azo dye splitting. Under increasing sludge concentration, hence, increasing metabolic activity per volume unit, the concentration and transport of reducing agents became less and less rate limiting for extracellular azo dye reduction.

\section{Effect of electron donor}

The primary electron donor may play a role in the biodegradation reactions in individual cultures by changing and stimulating enzyme activities and, in mixed cultures, by stimulating specific trophic groups of microorganisms (Van der Zee and Villaverde 2005). Some primary substrates may be better suitable 
for delivering reducing equivalents to the dyes during degradation reactions, either because of the substrate itself or because of the microorganisms involved. Ery $B$ biodegradation was tested with three different substrates (mixture VFA, glucose, and lactose) in order to study the effect of electron donor. The biomass concentration was $0.94 \mathrm{~g} \mathrm{VSS} \mathrm{L}^{-1}$, to diminish the dye removal by adsorption. Color removal from the solution occurred with all the tested substrates, which suggests that the process is relatively nonspecific with respect to its electron donor. Comparing the three substrates, better results were obtained with glucose and lactose. For those two substrates, similar degrees of decolorization $(\sim 35 \%)$ and rates $\left(\sim 1.0 \mathrm{~h}^{-1}\right)$ were obtained (Table 2$)$. With VFAs as substrate the degree and rate of decolorization was half of the obtained with glucose and lactose. This finding is in agreement with previous studies that investigated the role of various electron donors on the reduction of dyes, concluding that the rates vary with the type of substrate by stimulating specific microorganisms in a mixed culture (Van der Zee et al. 2001; Dos Santos et al. 2003). Li et al. (1999) have also concluded that the carbon sources could affect the biodegradation rates of the xanthene dye rose bengal. The use of different substrates may also affect the enzymatic reaction that take place for dye degradation, once also different enzymes may be involved in the reaction.

\section{Effect of biomass induction with dye}

The pre-incubation with lower amounts of dye (or other compounds) may activate (constitutive enzymatic system) or induce (inducible or adaptive enzymes) the genes for the expression of the enzymes involved on its degradation. Incubation is also important for living cells adaptation and sometimes can even

Table 2 Effect of different co-substrates on biological Erythrosine B $(0.3 \mathrm{mM})$ solution decolorization with noninduced and induced biomass $(0.03 \mathrm{mM}$ of dye) (the amount of biomass was $0.94 \mathrm{~g} \mathrm{VSS} \mathrm{L}^{-1}$ )

\begin{tabular}{|c|c|c|c|c|}
\hline \multirow[t]{2}{*}{ Substrate } & \multicolumn{2}{|c|}{ Decolorization (\%) } & \multicolumn{2}{|l|}{ Rate $\left(\mathrm{h}^{-1}\right)$} \\
\hline & $\begin{array}{l}\text { No } \\
\text { induction }\end{array}$ & Induction & $\begin{array}{l}\text { No } \\
\text { induction }\end{array}$ & Induction \\
\hline VFA & $17 \pm 5$ & $20 \pm 5$ & $0.5 \pm 0.1$ & $1.4 \pm 0.2$ \\
\hline Glucose & $36 \pm 3$ & $25 \pm 1$ & $1.2 \pm 0.1$ & $1.1 \pm 0.2$ \\
\hline Lactose & $38 \pm 2$ & $23 \pm 1$ & $0.8 \pm 0.2$ & $1.5 \pm 0.3$ \\
\hline
\end{tabular}

decrease the toxicity exerted by the compound. We have pre-incubated biomass with $0.03 \mathrm{mM}$ of Ery (10\% of the concentration tested in the further biodegradation assays). All the three co-substrates were again tested. Although the induction decreased the process efficiency with the substrates glucose and lactose (only $\sim 25 \%$ color removal), the rate was similar as with non induced biomass $\left(\sim 1 \mathrm{~h}^{-1}\right)$ with glucose as substrate and slightly higher $\left(\sim 1.5 \mathrm{~h}^{-1}\right)$ with lactose. The extent of solution decolorization with VFAs was maintained as in non-induced system ( $\sim 20 \%$ ), but biomass pre-incubation led to a $\sim$ threefold rate increase $\left(1.4 \pm 0.2 \mathrm{~h}^{-1}\right)$ (Table 2). With VFA, decolorization is almost the same (17-20\%) though that the rates almost triplicate. This may be due to the fact that the equilibrium is reached faster, but at the final of the experiment, the extent of decolorization is the same. With glucose and lactose, the extent of decolorization decreases. This may be due to experimental results: if we look to all results (Tables 1, 2, 3, 4, and 5), the extent of decolorization with biomass (without $\mathrm{AC}$ ), independent of the conditions, is always $\sim 20-30 \%$.

Since the differences between induced and noninduced biomass capacity for Ery B removal are very low, with the exception of reaction rate increase with VFAs as substrate, constitutive enzymes may be involved in the biodegradation. The rate increase may be due to the adaptation of the biomass to the dye, prior to the decolorization process. Constitutive fungal enzymes, involved in the degradation of the xanthene dye Rose Bengal, could also be stimulated by the preincubation with the dye ( $\mathrm{Li}$ et al. 1999).

\section{Activated carbon as redox mediator}

The transfer of reducing equivalents from a primary electron donor (co-substrate) to a terminal electron acceptor (azo dye) generally acts as the process rate limiting step in anaerobic azo dye reduction (Van der Zee et al. 2003). The large majority of the studies indicated the use of water-soluble compounds as redox mediators for azo dye reduction. Some investigations demonstrated redox-mediating properties of non-soluble materials.

The addition of redox mediators like quinones and flavine-based compounds has been shown to accelerate this electron transfer, and higher degradation rates can be achieved in bioreactors (Dos Santos et al. 2003; 
Cervantes et al. 2001). In recent studies it is specified that activated carbon, graphite, and alginate accelerate azo dye reduction in biological systems (Mezohegyi et al. (2007); Van der Zee et al. (2003); Van der Zee et al. 2003; Pereira et al. 2010; Guo et al. (2007); Van der Zee and Cervantes (2009)). Van der Zee and Cervantes (2009) indicated that activated carbon or other insoluble materials with surface-associated or entrapped redox-active functional groups can be considered valuable insoluble redox mediators.

The biological degradation results of Ery B in the presence of $0.1 \mathrm{~g} \mathrm{~L}^{-1}$ and $0.5 \mathrm{~g} \mathrm{~L}^{-1}$ of a commercial $\left(\mathrm{AC}_{0}\right)$ and structurally modified $\mathrm{AC}$ are presented in Tables 3 and 4. The first two lines from Table 3 presented the data obtained for Ery adsorption using two AC dosages (in the absence of biomass), line 3 and 4 presented the values obtained for Ery decolorization in the presence of two biomass concentration, but in the absence of $\mathrm{AC}$, the last two lines include the data

Table 3 Degrees and rates of Erythrosine B (0.3 mM) solution decolorization with different $\mathrm{AC}_{0}$ concentration ( 0.1 and $\left.0.5 \mathrm{~g} \mathrm{~L}^{-1}\right)$ and biomass (0.94 and $\left.3.77 \mathrm{~g} \mathrm{VSS} \mathrm{L}^{-1}\right)$

\begin{tabular}{lll}
\hline Conditions & $\begin{array}{l}\text { Decolorization } \\
(\%)\end{array}$ & Rate $\left(\mathrm{h}^{-1}\right)$ \\
\hline $\mathrm{AC}\left(0.1 \mathrm{~g} \mathrm{~L}^{-1}\right)$ no biomass & $10 \pm 3$ & $0.34 \pm 0.18$ \\
$\mathrm{AC}\left(0.5 \mathrm{~g} \mathrm{~L}^{-1}\right)$ no biomass & $46 \pm 1$ & $0.59 \pm 0.04$ \\
Biomass $\left(0.94 \mathrm{~g} \mathrm{VSS} \mathrm{L}^{-1}\right)$ & $20 \pm 4$ & $0.26 \pm 0.05$ \\
$\quad$ no AC & & \\
Biomass $\left(3.77 \mathrm{~g} \mathrm{VSS} \mathrm{L}^{-1}\right)$ & $66 \pm 1$ & $1.36 \pm 0.20$ \\
$\quad$ no AC & & \\
$\mathrm{AC}\left(0.1 \mathrm{~g} \mathrm{~L}^{-1}\right)+$ biomass & $26 \pm 3$ & $0.61 \pm 0.01$ \\
$\quad\left(0.94 \mathrm{~g} \mathrm{VSS} \mathrm{L}^{-1}\right)$ & & \\
$\mathrm{AC}\left(0.5 \mathrm{~g} \mathrm{~L}^{-1}\right)+$ biomass & $56 \pm 3$ & $0.63 \pm 0.15$ \\
$\quad\left(0.94 \mathrm{~g} \mathrm{VSS} \mathrm{L}^{-1}\right)$ & & $1.44 \pm 0.32$ \\
$\mathrm{AC}\left(0.1 \mathrm{~g} \mathrm{~L}^{-1}\right)+$ biomass & $72 \pm 3$ & \\
$\quad\left(3.77 \mathrm{~g} \mathrm{VSS} \mathrm{L}^{-1}\right)$ & & \\
$\mathrm{AC}\left(0.5 \mathrm{~g} \mathrm{~L}^{-1}\right)+$ biomass & $80 \pm 2$ & \\
$\quad\left(3.77 \mathrm{~g} \mathrm{VSS} \mathrm{L}^{-1}\right)$ & & \\
\hline
\end{tabular}

obtained in the experiments conducted both in the presence of biomass and AC.

Although the similar degree of Ery B solution decolorization with $0.94 \mathrm{~g} \mathrm{VSS} \mathrm{L}^{-1}$ of biomass either in the non-mediated or mediated $\left(0.1 \mathrm{~g} \mathrm{~L}^{-1} \mathrm{AC}_{0}\right)$ assays, the rate almost duplicated which suggests that enzymatic degradation occurs. With higher biomass concentration, $3.77 \mathrm{~g} \mathrm{VSS} \mathrm{L}^{-1}$, degrees and rates of solution decolorization were independent of the presence of $\mathrm{AC}_{0}$. It is worth to mention that the use of five times more $\mathrm{AC}$ does not led to an increase of the rates, but lead to an increase of color removal from the medium, specially with $0.94 \mathrm{~g} \mathrm{VSS} \mathrm{L}^{-1}$ of biomass (almost the double), probably due to adsorption phenomena. Indeed, in the adsorption assays only with the commercial $\mathrm{AC}_{0}, \mathrm{a} \sim$ fivefold increase of dye adsorption on the material was obtained by increasing the AC concentration from 0.1 to $0.5 \mathrm{~g} \mathrm{~L}^{-1}$. The use of small amounts is of utmost importance due to the excessive costs of AC (Pereira et al., 2010). In the biological assays with different treated AC samples, the degree of solution color decrease is very similar for all the conditions (25-30\%), except with $\mathrm{AC}_{\mathrm{HNO}_{3}}$ with lower extent, only $15 \%$, but the rates increased with the increase of sample basicity, i.e., with increase of $\mathrm{pH}_{\mathrm{pzc}}$ (Table 4). As can be seen in Table 4, the presence of $\mathrm{AC}$ accelerates the reaction. With $\mathrm{AC}_{\mathrm{HNO}_{3}}$ and $\mathrm{AC}_{\mathrm{O}_{2}}$, there is no adsorption (only 1-3\% decolorization). If the decolorization extent in the presence of the different AC samples is always in the same order and the rate increases (two to threefold), that means that a reaction occurs.

In the presence of $\mathrm{AC}_{\mathrm{H}_{2}}$, the rate is almost the triple as in the absence of $\mathrm{AC}$ and the double as compared with other treated samples. The $\mathrm{pH}_{\mathrm{pzc}}(\mathrm{pH}$ of the point of zero charge) is a critical value for determining quantitatively the net charge (positive or negative) carried on the AC surface as a function of the solution $\mathrm{pH}$. The assay was performed at $\mathrm{pH} 7$ and
Table 4 Biological decolorization of Erythrosine B solution $(0.3 \mathrm{mM})$ with different $\mathrm{AC}$ samples $\left(0.1 \mathrm{~g} \mathrm{~L}^{1}\right)$. Biomass concentration of $0.94 \mathrm{~g} \mathrm{VSS} \mathrm{L}^{-1}$

\begin{tabular}{lcll}
\hline AC sample & No biomass & Biomass \\
\cline { 3 - 4 } & \% Decolorization & \% Decolorization & Rate $\left(\mathrm{h}^{-1}\right)$ \\
\hline No $\mathrm{AC}$ & - & $20 \pm 4$ & $0.26 \pm 0.05$ \\
$\mathrm{AC}_{\mathrm{HNO}_{3}}\left(\mathrm{pH}_{\mathrm{pzc}}=2.7\right)$ & $3 \pm 3$ & $15 \pm 1$ & $0.44 \pm 0.00$ \\
$\mathrm{AC}_{\mathrm{O}_{2}}\left(\mathrm{pH}_{\mathrm{pzc}}=4.5\right)$ & $1 \pm 1$ & $24 \pm 1$ & $0.62 \pm 0.23$ \\
$\mathrm{AC}_{0}\left(\mathrm{pH}_{\mathrm{pzc}}=8.4\right)$ & $10 \pm 1$ & $23 \pm 3$ & $0.61 \pm 0.01$ \\
$\mathrm{AC}_{\mathrm{H}_{2}}\left(\mathrm{pH}_{\mathrm{pzc}}=9.2\right)$ & $12 \pm 4$ & $29 \pm 1$ & $0.90 \pm 0.03$ \\
\hline
\end{tabular}


for $\mathrm{pH}>\mathrm{pH}_{\mathrm{pzc}}$, $\mathrm{AC}$ becomes negatively charged, what is the case of $\mathrm{AC}_{\mathrm{HNO}_{3}}$ and $\mathrm{AC}_{\mathrm{O}_{2}}$ (Pereira et al. 2010). Once the dye is anionic, the repulsion between $\mathrm{AC}$ and dye will increase. These phenomena impede the electron changes and, consequently, the adsorption of the dye on AC. On the other hand, when $\mathrm{pH}<\mathrm{pH}_{\mathrm{pzc}}, \mathrm{AC}$ becomes positively charged (as the case of $\mathrm{AC}_{0}$ and $\mathrm{AC}_{\mathrm{H}_{2}}$ ) and attraction between $\mathrm{AC}$ and anionic dye occurs, resulting an increase in dye adsorption. Indeed, in the controls without biomass, decolorization was obtained, though at low degree, only in the solutions containing $\mathrm{AC}_{0}$ and $\mathrm{AC}_{\mathrm{H}_{2}}$ $(\sim 10 \%)$.

The isotherms of Ery adsorption on $\mathrm{AC}_{0}$ were also determined. The Langmuir $\left(K_{L}\right)$ and Freundlich constants $\left(K_{F}\right)$ and the correlation coefficients are presented in Table 5. The values of the correlation coefficients, $\sim 0.99$, indicated that data fit well to both isotherms model. The essential feature of the Langmuir isotherm can be expressed by means of $R_{L}$, a dimensionless constant referred to as separation factor or equilibrium parameter. The values of $R_{L}$ indicate the shape of isotherms to be either favorable $\left(0<R_{L}<1\right)$, unfavorable $\left(R_{L}>1\right)$, linear $\left(R_{L}=1\right)$ or irreversible $\left(R_{L}=0\right)$. The $\mathrm{R}_{\mathrm{L}}$ values obtained in our study, 0.148 , indicated that Ery adsorption on $\mathrm{AC}_{0}$ was a favorable process. The Freundlich constant $K_{F}$ and n are the indicative of the extent of the adsorption and the degree of nonlinearity between solution concentration and adsorption. The slope range between 0 and 1 is a measure of surface heterogeneity, becoming more heterogeneous as its value gets closer to zero. The sorption intensity is given by $n$. The value of $n$ above one, 3.44 , means that the adsorption took place by chemical interactions between dye and AC.

Table 5 Adsorption of Erythrosine B on Activated Carbon $\left(\mathrm{AC}_{0}\right)$ : Langmuir $\left(K_{L}\right)$ and Freundlich $\left(K_{F}\right)$ isotherm constants. $X m$ is the limiting amount of adsorbate that can be taken up per mass of adsorbent (mg Ery $\mathrm{g}^{-1} \mathrm{AC}$ ) and $\mathrm{n}$ is a constant of the Freundlich isotherm

\begin{tabular}{lllll}
\hline Isotherm type & \multicolumn{2}{l}{ Parameter } & & \\
\hline & $X m$ & $K_{L}$ & $R_{L}$ & $R^{2}$ \\
Langmuir & 416.66 & 0.023 & 0.148 & 0.9809 \\
& & $K_{F}$ & $n$ & $R^{2}$ \\
\multirow{2}{*}{ Freundlich } & & 75.24 & 3.44 & 0.9824 \\
\hline
\end{tabular}

\section{Effect of $p H$}

The effect of $\mathrm{pH}$ on Ery B degradation was tested at $\mathrm{pH}$ values of 6.0 and 7.0, in the presence and absence of activated carbon $\left(\mathrm{AC}_{0}\right)$. The ideal $\mathrm{pH}$ range for anaerobic digestion is very narrow, between 6.8 and 7.2. The growth rate of methanogens is greatly reduced below pH 6.6 (Mosey and Fernandes 1989). Though the optimal $\mathrm{pH}$ of methanogenesis being around 7.0, the optimum $\mathrm{pH}$ of hydrolysis and acidogenesis has been reported in the range between pH 5.5 and 6.5 (Adebiyi et al. 2011; Sohrabnezhad et al. 2010). By those reasons, we have only tested this two $\mathrm{pH}$ values, 6.0 and 7.0. In the dye solutions without AC, the decolorization percentage was threefold higher at $\mathrm{pH} 6.0,36 \pm 3 \%$, as compared with the decolorization at $\mathrm{pH} 7.0,13 \pm 4 \%$, (data not shown). The decrease of the $\mathrm{pH}$ has also duplicated the rate of the reaction: $0.85 \pm 0.11 \mathrm{~h}^{-1}$ and $0.42 \pm 0.05 \mathrm{~h}^{-1}$ at $\mathrm{pH} 6.0$ and $\mathrm{pH} 7.0$, respectively. The presence of $\mathrm{AC}$ in the reaction solution did not affect significantly either the decolorization percentage or reaction rates at pH $6.0\left(37 \pm 4 \%\right.$ and $\left.0.88 \pm 0.14 \mathrm{~h}^{-1}\right)$. Contrarily, at $\mathrm{pH} 7.0$, an increase of both was obtained when the mediator was present $(26 \pm 3 \%$ and $0.61 \pm 0.01$ $\mathrm{h}^{-1}$ ). Though, the results were worse than the obtained with lower $\mathrm{pH}$.

\section{Adsorption of Ery B on biomass}

In biotic assay without carbon source and nutrients, the removal percentage of Ery B from the medium was lower than in the presence of nutrients, $47 \pm 5$ and $68 \pm 1 \%$, respectively (data not shown). The result suggests the occurrence of both phenomena on the dye decrease, adsorption, and enzymatic degradation. Even without the addition of exogenous sources of carbon and electrons, sludge can use endogenous energy reserves for dye removal, justifying the $47 \%$. Additionally, biodegradable organics may be introduced within the sludge. When dye removal is only due to the physical process of adsorption, the color is eliminated, but the dye remains in the solid phase. With both phenomena, first the dye is adsorbed and then enzymatically degraded by the cells. In the abiotic experiments, with autoclaved biomass, the degree of dye removal is the same as with active biomass, $69 \pm 1 \%$. This result may lead to the opposite conclusion that dye removal derives only 
from the adsorption on cells. Although, the process of autoclaving may change the cell membranes of the microorganisms and also the granular sludge morphology facilitating the adsorption of dye, as compared with active and in perfect conditions cells. Interestingly, when the biomass was inhibited with gluteraldehyde and formaldehyde, the color removal from the solution was much higher, $90 \pm 1 \%$. The inhibition process may have caused changes in cell membrane, such as zeta potential (i.e., the surface charge), which have affected the dye adsorption and also degradation. To explain this result, further studies of cell microbiology should be made.

\section{Effect of dye concentration}

The kinetic of Ery degradation by $3.77 \mathrm{~g} \mathrm{VSS} \mathrm{L}^{-1}$ of biomass was studied with different initial dye concentrations (Fig. 3a). The other xanthene dye with similar structure, Eosin Y, was also tested for comparison (Fig. 3b). The difference between the molecules is the substitution of the four iodine atoms in Ery to four bromide atoms in Eosin. It is merit to make a note that, contrarily to the observed with Ery, the centrifugation of the reaction medium containing Eos, the granules were colorless, suggesting that Eos did not adsorbed on cells during the process. In terms of kinetics, similar behavior was observed for both dyes, first-order rates increased with increasing the dye concentration followed by a decrease at higher dye amounts, $0.4 \mathrm{mM}$ of Ery and $0.9 \mathrm{mM}$ of Eos. The maximal rates were $1.08 \pm 0.09 \mathrm{~h}^{-1}$ for Ery and $2.97 \pm 0.22 \mathrm{~h}^{-1}$ for Eos. Inhibitory effect at high dye concentration occurred with both dyes, being higher for Ery. In anaerobic processes, dyes are used as final electron compounds and the co-substrate as electron donors, at higher dye concentrations probably the bacteria can use also dyes as co-substrate and a competition between both substrates may result in kinetics inhibition. Other possibility may be the toxicity exerted by the dyes when used at high levels. Inhibition kinetics was also reported by other authors for the degradation of azo (Pereira et al. 2009) and anthraquinone dyes (Adebiyi et al. 2011). In this study, a complex system is present, where more than one microorganism from the sludge and many enzymes may be involved, instead of a single enzymatic reaction.
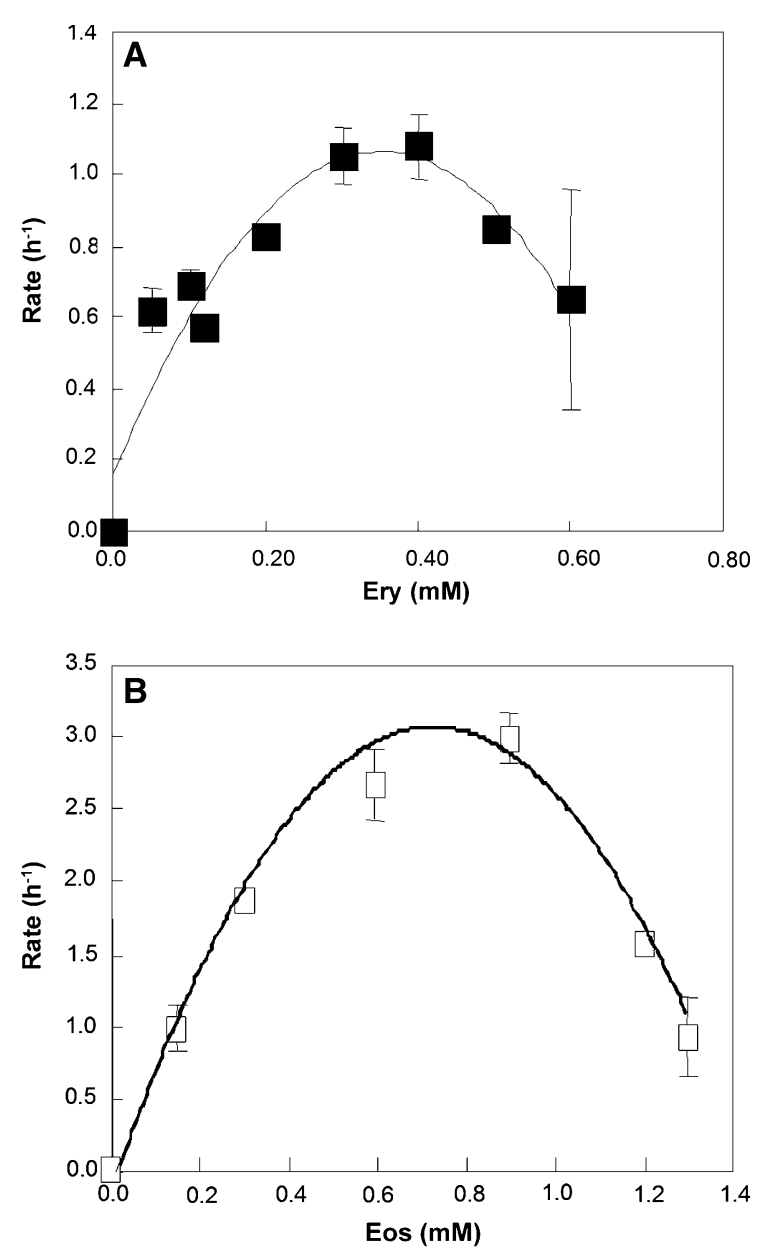

Fig. 3 Rates of Erythrosine B (a) and Eosine (b) decolorization at increasing dye concentrations. Biomass concentration of $3.77 \mathrm{~g} \mathrm{VSS} \mathrm{L}^{-1}$

\section{Chemical reduction of Ery B}

Chemical Ery B reduction was tested with sulphide at different $\mathrm{pH}$ values. By a visual screening of the dyed solution, no significant decolorization was observed at concentrations of $1 \mathrm{mM}$ to $6 \mathrm{mM}$ of $\mathrm{Na}_{2} \mathrm{~S}$. Increasing the $\mathrm{Na}_{2} \mathrm{~S}$ to $100 \mathrm{mM}$, the color changed from pink to purple. In the visible spectra, a decrease of the absorbance of the dye was followed by an increase of absorbance at around $600 \mathrm{~nm}$ reaching the equilibrium after $20 \mathrm{~h}$, due to the formed products of dye reduction (data not shown). The percentage of color removal was $43 \pm 6 \%$. The results confirm that the xanthene dye Ery B is a high recalcitrant dye towards anaerobic reduction, once a very high amount of sulphide is necessary to cause its degradation. As 
postulated by other authors, for the reduction of azo dyes by sulphide, according to the stoichiometry of dye reduction by sulphide, $2 \mathrm{~mol}$ of sulphide are required per mole of azo dye when sulphide is oxidized to elemental sulphur (Van der Zee et al. 2003; Pereira et al. 2010; Sohrabnezhad et al. 2010). For xanthene dye reduction, any previous work is available.

\section{Conclusions}

A screening of dye biodegradation with anaerobic granular biomass showed its capacity to degrade all the azo dyes tested. In the similar reaction conditions, the two xanthene dyes, Ery and Eos, were degraded at lower extent. Many factors were studied, for the first time, on the biological Ery dye reduction. With increasing biomass amounts, maximum color removal efficiency of $72 \%$ was achieved with $4.71 \mathrm{~g} \mathrm{VSS} \mathrm{L}^{-1}$ biomass. Inhibition at high dye concentration was observed with a maximum rate at $0.4 \mathrm{mM}$. Substrate inhibition was also obtained with Eos Y, for concentrations higher than $0.9 \mathrm{mM}$. No considerable effects using different substrates as electron donors (VFA, glucose or lactose) were obtained. Induction of biomass with little amounts of Ery B decreased the percentage dye removal from the reaction solution, but accelerated the reaction. Although the similar degree of Ery B degradation with $0.94 \mathrm{~g} \mathrm{VSS} \mathrm{L}^{-1}$ of biomass either in the non-mediated or mediated $\left(0.1 \mathrm{~g} \mathrm{~L}^{-1}\right.$ $\mathrm{AC}_{0}$ ) assays, the rate almost duplicated in the presence of the catalyst, which suggests that enzymatic degradation occurs. That phenomenon was not observed for higher biomass concentration. The use of five times more AC does not led to an increase of the rates, but an increase of color removal was achieved. Using different modified AC samples, better results occurred with the most basic one, 1.5-fold and threefold higher rates with $\mathrm{AC}_{\mathrm{H}_{2}}$, as compared with non-treated $\mathrm{AC}$ $\left(\mathrm{AC}_{0}\right)$ and non-mediated reaction, respectively. Decreasing the $\mathrm{pH}$ from 7.0 to 6.0 resulted in a threefold improvement of Ery degradation rate. Chemically Ery B reduction occurred only with high $\mathrm{Na}_{2} \mathrm{~S}$ concentration, $100 \mathrm{mM}$. Our results led to the conclusion that decolorization of Ery containing solutions may be due to enzymatic and adsorption phenomena. Biodegradation products will be provided in future publications.
Acknowledgments This work was supported by the PTDC/ AMB/69335/2006 project grants (Fundação para a Ciência e Technologia, FCT, Portugal), BRAIN project (ID 6681, European Social Found and Romanian Government and the grant of the Romanian National Authority for Scientific Research, CNCS-UEFISCDI, project number PN-II-ID-PCE2011-3-0559, Contract 265/2011.

\section{References}

Adebiyi AO, Togo AC, Mutanda T, Slatter C, Whiteley CG (2011) Decolourisation and degradation of reactive blue 2 by sulphate reducing bacteria (SRB) and zero valent iron in a biosulphidogenic reactor. Afr J Biotechnol 10:584-588

Apostol LC, Gavrilescu M (2009) Application of natural materials as sorbents for persistent organic pollutants. Environ Eng Manag J 8:243-252

Aretxaga A, Romero S, Sarrà M, Vicent T (2001) Adsorption step in the biological degradation of a textile dye. Biotechnol Prog 17:664-668

Artvinli S (1975) Biochemical aspects of aldehyde fixation and a new formaldehyde fixative. Histochem J 7:435-450

Bakshi DK, Gupta KG, Sharma P (1999) Enhanced biodecolorization of synthetic textile dye effluent by Phanerochaete chrysosporium under improved culture conditions. World J Microbiol Biotechnol 15:507-509

Cailean D, Barjoveanu G, Musteret CP, Sulitanu N, Manea LR, Teodosiu C (2009) Reactive dyes removal from wastewater by combined advanced treatment. Environ Eng Manag J 8:503-511

Caliman FA, Gavrilescu M (2009) Pharmaceuticals, personal care products and endocrine disrupting agents in the environment-a review. Clean-Soil Air Water 37:277303

Cervantes FJ, Van der Zee FP, Lettinga G, Field JA (2001) Enhanced decolourisation of Acid Orange 7 in a continuous UASB reactor with quinones as redox mediators. Water Sci Technol 44:123-128

Cervantes FJ, Enríquez JE, Galindo-Petatán E, Arvayo H, RazoFlores E, Field JA (2007) Biogenic sulphide plays a major role on the riboflavin-mediated decolourisation of azo dyes under sulphate-reducing conditions. Chemosphere 68 : 1082-1089

Costa JC, Moita I, Ferreira EC, Alves MM (2009) Morphology and physiology of anaerobic granular sludge exposed to an organic solvent. J Hazard Mater 167:393-398

Crini G (2006) Non-conventional low-cost adsorbents for dye removal: a review. Bioresour Technol 97:1061-1085

Dos Santos AB, Cervantes FJ, Yaya-Beas RE, Van Lier JB (2003) Effect of redox mediator, AQDS, on the decolourisation of a reactive azo dye containing triazine group in a thermophilic anaerobic EGSB reactor. Enzyme Microb Technol 33:942-951

Dos Santos AB, Bisschops IAE, Cervantes FJ, Van Lier JB (2004) Effect of different redox mediators during thermophilic azo dye reduction by anaerobic granular sludge and comparative study between mesophilic $\left(30^{\circ} \mathrm{C}\right)$ and thermophilic $\left(55^{\circ} \mathrm{C}\right)$ treatments for decolourisation of textile wastewaters. Chemosphere 55:1149-1157 
Firmino PIM, Da Silva MER, Cervantes FJ, Dos Santos AB (2010) Colour removal of dyes from synthetic and real textile wastewaters in one- and two-stage anaerobic systems. Bioresour Technol 101:7773-7779

Gavrilescu M (2009) Behaviour of persistent pollutants and risks associated with their presence in the environmentintegrated studies. Environ Eng Manag J 8:1517-1531

Gavrilescu M, Chisti Y (2005) Biotechnology, a sustainable alternative for chemical industry. Biotechnol Adv 23:471499

Guo J, Zhou J, Wang D, Tian C, Wang P, Salah Uddin M (2007) Biocalalyst effects of immobilized anthraquinone on the anaerobic reduction of azo dyes by the salt tolerant bacteria. Water Res 41:426-432

Itoh K, Yatome C (2004) Decolorization and degradation of xanthene dyes by a white rot fungus, Coriolus versicolor. J Environ Sci Health Part A-Toxic/Hazard Subst Environ Eng A39:2383-2389

Jesus GJ, Corso CR, Campos A, Franchetti SMM (2010) Biodegradation of Erythrosin B dye by paramorphic Neurospora crassa 74A. Braz Arch Biol Technol 53:473-480

Kalyuzhnyi S, Yemashova N, Fedorovich V (2006) Kinetics of anaerobic biodecolourisation of azo dyes. Water Sci Technol 54:73-79

Karatas M, Dursun S, Argun ME (2009) Decolorization of reactive dyes under batch anaerobic condition by mixed microbial culture. Afr J Biotechnol 8:6856-6862

Khammuang S, Sarnthima R (2009) Mediator-assisted Rhodamine $\mathrm{B}$ decolourization by Tramates veriscolor Laccase. Pak J Biological Sci 12:616-623

Krilov SN, Chebotareva AB (1993) Peroxidase-catalyzed cooxidation of indole-3-acetic acid and xanthene dyes in the absence of hydrogen peroxide. FEBS Lett 324:6-8

Lan J, Huang X, Hu M, Li Y, Qu Y, Gao P, Wu D (2006) High efficient degradation of dyes with lignin peroxidase coupled with glucose oxidase. J Biotechnol 123:483-490

Li C, Bai J, Liu YC (1999) Identification and properties of xanthene dye decolorization of Aspergillus wentii Wehmer $\mathrm{HD}_{1}$. Mycosystema (Acta Mycologica Sinica) 18:67-72

Mezohegyi G, Kolodkin A, Castro UI, Bengoa C, Stuber F, Font J (2007) Effective anaerobic decolorization of azo dye Acid Orange 7 in continuous upflow packed-bed reactor using biological activated carbon system. Ind Eng Chem Res 46:6788-6792

Momenzadeh H, Tehrani-Bagha AR, Khosravi A, Gharanjig K, Holmberg K (2011) Reactive dye removal from wastewater using a chitosan nanodispersion. Desalination 271:225230

Mosey FE, Fernandes XA (1989) Patterns of hydrogen in biogas from the anaerobic-digestion of milk-sugars. Water Sci Technol 21:187-196
Ong SA, Toorisaka E, Hirata M, Hano T (2005) Biodegradation of redox dye methylene blue by up-flow anaerobic sludge blanket reactor. J Hazard Mater B124:88-94

Pearce CI, Lloyd JR, Guthrie JT (2003) The removal of colour from textile wastewater using whole bacterial cells: a review. Dyes Pigm 58:179-196

Pereira L, Coelho AV, Viegas CA, Dos Santos MMC, Robalo MP, Martins LO (2009) Enzymatic biotransformation of the azo dye Sudan Orange $\mathrm{G}$ with bacterial CotA-laccase. J Biotechnol 139:68-77

Pereira L, Pereira R, Pereira MFR, Van der Zee FP, Cervantes FJ, Alves MM (2010) Thermal modification of activated carbon surface chemistry improves its capacity as redox mediator for azo dye reduction. J Hazard Mater 183:931939

Potgieter JH (1991) Adsorption of methylene blue on activated carbon. J Chem Educ 68:348-350

Saratale RG, Saratale GD, Chang JS, Govindwar SP (2011) Bacterial decolorization and degradation of azo dyes: a review. J Taiwan Inst Chem Eng 42:138-157

SenthilKumar P, Umaiyambika N, Gayathri R (2010) Dye removal from aqueous solution by electrocoagulation process using stainless steel electrodes. Environ Eng Manag J 9:1031-1037

Sohrabnezhad S, Pourahmad A, Rakhshaee R, Radaee A, Heidarian S (2010) Catalytic reduction of methylene blue by sulphide ions in the presence of nanoAlMCM-41 material. Superlattices Microstructures 47:411-421

Van der Zee FP, Cervantes FJ (2009) Impact and application of electron shuttles on the redox (bio)transformation of contaminants: a review. Biotechnol Adv 27:256-277

Van der Zee FP, Villaverde S (2005) Combined anaerobicaerobic treatment of azo dyes - a short review of bioreactor studies. Water Res 39:1425-1440

Van der Zee FP, Lettinga G, Field JA (2000) The role of (auto)catalysis in the mechanism of an anaerobic azo reduction. Water Sci Technol 42:301-308

Van der Zee FP, Lettinga G, Field JA (2001) Azo dye decolourisation by anaerobic granular sludge. Chemosphere 44:1169-1176

Van der Zee FP, Bisschops IA, Lettinga G, Field JA (2003) Activated carbon as an electron acceptor and redox mediator during the anaerobic biotransformation of azo dyes. Environ Sci Technol 37:402-408

Venkata Mohan SR, Devi MP, Reddy MV, Chandrasekhar K, Juwarkar A, Sarma PN (2011) Bioremediation of petroleum sludge under anaerobic microenvironment: influence of biostimulation and bioaugmentation. Environ Eng Manag J 10:1609-1616 